UDC 631.111.4(334.72)

JEL: Q15,Q14

\author{
Hanna Tiutiunnyk \\ Postgraduate \\ Institute of Market Problems and \\ Economic and Ecological Research \\ NAS of Ukraine, \\ Odessa, Ukraine \\ E-mail: ecoregnaturres@ukr.net \\ orcid.org/0000-0003-4864-6129
}

Received: December, 2017

Accepted: February, 2018

(C) Economics. Ecology. Socium, 2018

CC BY-NC 4.0 license

\section{ECONOMIC AND ENVIRONMENTAL ASPECTS \\ OF ORGANIZATION THE TERRITORY OF ECOLOGICALLY CLEAN AGRICULTURAL LAND}

Introduction. The foundation of the creation of ecologically clean land masses is the economic organization of the territory. The leading component of ecologically safe land use is the need to determine the suitability of land soils for the cultivation of raion crops and the maintenance of maximum soil quality adapted to the quality of crop rotation.

Aim and tasks. In the article the purpose of planning the organization of land mass structures is determined. The task of the internal land management is to formulate a strategy for using land masses that would maximally focus on the actions of land users in optimizing, transforming and using land to the natural conditions of the region.

Research results. Measures to create ecologically pure land masses are carried out directly at agricultural enterprises, therefore, agricultural land use is a prerequisite for them. The organization of agricultural land use envisages for business entities, the establishment of a warehouse, the transformation of lands and conservation of degraded and low productivity land, which at the present stage has become the most effective factor in the environmental optimization of land use. Agroecological organization of the territory includes measures on four systemic properties of agroecosystems: productivity, stability, stability and uniformity. All four properties are interrelated in agroecosystems. Without these links it is impossible to organize the territory in order to create conditions for rational use and protection of land, which is demanded by the agricultural land management system.

Conclusion. In the article the necessity of characterization of qualitative and quantitative characteristics of lands is grounded in order to find out the influence of the creation of the land mass and the appearance of possible dangers. The basic stages of the transition to environmentally safe agriculture and the formation of ecologically clean land masses have been determined. The types of development of the land mass are described: one-time and step-bystep. The complex problems that may be encountered by an enterprise of any ownership type in the transition to the maintenance of ecologically pure agriculture are determined. Creation of ecologically pure massifs of lands and agroecological organization of the territory includes a system of measures for the adaptation of agricultural production, agriculture to the peculiarities of the natural environment, along with the system of levers of state management of rational ecologically safe use of agricultural land. So the necessity of state support and motivation for enterprises planning to switch to the production of ecologically clean products and the formation of ecologically clean land masses has been substantiated.

Keywords: ecologically clean land, land masses, natural environment, agroecological organization, enterprise, ecologically pure massifs. 


\section{УДК 631.111.4(334.72) JEL: Q15, Q14}

\section{Ганна Тютюнник}

Аспірант, Інститут проблем ринку та економіко-екологічних досліджень НАН України, Одеса, Україна

E-mail: ecoregnaturres@ukr.net orcid.org/0000-0003-4864-6129

Отримано: Грудень, 2017 Прийнято: Лютий, 2018

(C) Економіка. Екологія. Соціум, 2018 CC BY-NC 4.0ліцензія

\section{ЕКОНОМІКО-ЕКОЛОГІЧНІ АСПЕКТИ ОРГАНІЗАЦІЇ ТЕРИТОРІЇ ЕКОЛОГІЧНО ЧИСТИХ СІЛЬСЬКОГОСПОДАРСЬКИХ ЗЕМЕЛЬ}

Проблема. У статті розглянуто роль та шляхи організації екологічно чистих земель сільськогосподарського призначення. Основою створення екологічно-чистих земельних масивів $\epsilon$ внутрішньогосподарська організація території. Провідною складовою екологічно-безпечного землекористування потребує бути визначення придатності грунтів земельних ділянок для вирощування районованих сільгоспкультур і ведення максимально пристосованих до якості грунтового покриву сівозміною. Визначені комплексні проблеми, з якими може зіткнутися підприємство будь-якої форми власності при переході на ведення екологічно чистого землеробства.

Мета та завдання. Визначено мету планування організації земельних масивів. Обгрунтовано основні етапи переходу на екологічно безпечне землеробство і формування екологічно чистих земельних масивів.

Результати. Охарактеризовано типи освоєння земельного масиву: одноразовий і поетапний. Доведено необхідність якісних та кількісних характеристик земель 3 метою з'ясування впливу створення земельних масивів та появи можливих небезпек. Визначено, що завданням внутрішньогосподарського управління територією $\epsilon$ формування стратегії використання земельних масивів, що максимально орієнтована на дії землекористувачів в оптимізації, перетворенні та використанні землі в природних умовах регіону.

Заходи щодо створення екологічно чистих масивів земель здійснюються безпосередньо на сільськогосподарських підприємствах, отже, організація сільськогосподарського землекористування $є$ необхідною умовою для них. Організація сільськогосподарського землекористування передбачає для суб'єктів господарювання, встановлення складу, трансфомарцію угідь та збереження деградованої та малопродуктивної землі, яка на сучасному етапі стала найефективнішим фактором екологічної оптимізації землекористування. Обгрунтовано необхідність державної підтримки та мотивації для підприємств, які планують перейти на виробництво екологічно чистих продуктів та формування екологічно чистих земельних масивів.

Висновки. Створення екологічно чистих масивів земель та агроекологічної організації території включає в себе систему заходів щодо адаптації сільськогосподарського виробництва, сільського господарства до особливостей природного середовища, а також системи важелів державного управління раціональним екологічно безпечним використанням сільськогосподарської продукції. Агроекологічна організація території включає заходи щодо чотирьох системних властивостей агроекосистем: продуктивність, стабільність та однорідність. Всі чотири властивості взаємопов'язані в агроекосистемах. Без цих зв'язків неможливо організувати територію для створення умов щодо раціонального використання та охорони земель, яка вимагається системою землеустрою сільськогосподарського призначення.

Ключові слова. екологічно чиста земля, земельні масиви, природне середовище, агроекологічна організація, підприємство, екологічно чисті масиви. 
Introduction. The foundation of the creation of ecologically clean land masses is the economic organization of the territory. The leading component of ecologically safe land use is the need to determine the suitability of land soils for the cultivation of raion crops and the maintenance of maximum soil quality adapted to the quality of crop rotation [1].

Analysis of recent research. Investigation of scientific issues related to the organization of the territory of agricultural enterprises has been reflected in the works of A. Antipov, YU.M. Semenov [2], A.Ya.Sokhnich, P.P. Kolodiy [4], and others.

Aim and tasks. The task of the organization of the territory of ecologically clean agricultural land is to formulate a strategy for using land masses that would maximally focus on the actions of land users in optimizing, transforming and using land to the natural conditions of the region.

Measures to create the ecologically clean land masses are carried out directly at agricultural enterprises, therefore, agricultural land is a prerequisite for them. The organization of agricultural land envisages for business entities, the establishment of a warehouse, the transformation of land and the conservation of degraded and low-productive land.

Main results. The purpose of land-use planning is to ensure that important attributes of land use are sustainable. These attributes are divided into three groups: infrastructure objects incl. natural resources (e.g. open spaces, river basins, natural areas and wetlands) and public safety (e.g., the avoidance of floodplains, unstable soils and fire danger).

The sustainability of land use for its further usage in agricultural circulation and acquisition the desired results is closely linked to the agro-environmental organization of the territory. So agroecological organization of land is a set of measures for agricultural land use with the purpose of obtaining crop and livestock products while preserving agricultural resources (soil cover, natural forage lands, hydrological resources of agroecosystems), biodiversity and simultaneous protection against pollution of the environment and the resulting products.
Agroecological organization of the territory includes measures on four systemic properties of agroecosystems: productivity, stability, stability and uniformity. All four properties are interrelated in agroecosystems. Without these links it is impossible to organize the territory in order to create conditions for rational use and protection of land, which is demanded by the agricultural land management system.

Mandatory attention should be paid to the definition of the danger of impact on the development of land, which will allow the development of alternative approaches to the achievement of goals (for example, provisions, privileges, as well as public procurement), to select and implement the best.

An important step in the land use planning is to find out how the use of land will affect the current local conditions. The process initiates a collection of stakeholders to work with environmentalists to identify the areas that need to be restored. This group includes developers, landowners, designers, environmental advocates for decision making.

Thus, with the introduction of agricultural use of ecologically clean land masses, it will be possible to observe significant improvements in the quality state of local conditions, namely, improvement of the chemical status of soils, restoration of bioproductivity of land, increase of resistance of agricultural crops to negative factors of influence.

Characteristics of land use should be compared, and a composite map is created to illustrate the district. This map is used to designate territories as a requirement for approval of all proposed events. If the state of land use is characterized by the manifestation of risks due to the effects of negative processes, then a number of mitigation measures must be taken. Such measures include the provision of kickbacks, the application of special rules and agreements.

The investigated area is subject to the diagnosis of the presence of environmentally sensitive areas before preparing proposals for the implementation of the project, which includes the development of criteria for assessing the sensitivity and importance of individual natural components; zoning of the 
territory according to the values and sensitivity of individual natural components for the implementation of the target sectoral function; zone zoning according to sectoral goals; definition of types of measures and their planning in accordance with the branches of the economy [2].

If in the middle of the land mass, which is subject to the transition to ecologically clean available contaminated land, an important part of the transformation of the territory is the determination of soil contamination by the indicator plants and the classification of land use pollution, as well as the implementation of restorative and protective measures of the land masses. One of these regenerative methods is extraction by natural substances, which stimulates the redistribution of pollutants from solid phase to solution, for selective removal of contamination. Contaminated soil is excavated and processed outside the land massif. After processing, the soil returns to the original place.

Among the biological methods for the elimination of pollutants, the current technology, ecologically clean and inexpensive, which uses the metabolic diversity of some microorganisms to decompose and reduce the concentration of toxic compounds is considered bioweaving. Biological disposal or (bioprocessing / bio-recovery) is a process of mineralization of toxic compounds by aerobic organisms, mainly indigenous, to inorganic forms (CO2 та $\mathrm{H} 2 \mathrm{O})$. Despite a number of effective measures, there are land that does not recover at all, that is, those that are subject to temporary withdrawal from agricultural use for the protection and protection of other land masses (Table 1).

Table 1. The main indicators characterizing the soil properties and necessitating the withdrawal of agricultural land from agricultural and agricultural areas

\begin{tabular}{|c|c|c|c|}
\hline No. & $\begin{array}{l}\text { Properties and soil } \\
\text { characteristics }\end{array}$ & Units of measurement & $\begin{array}{l}\text { Indicators of soil properties (taking into } \\
\text { account the zonal location) }\end{array}$ \\
\hline 1 & Radiation pollution & $\begin{array}{l}\text { Density of terrain cesium-137, } \\
\text { strontium }-90 \text {, Qi / } \mathrm{km} . \mathrm{km}\end{array}$ & Cs-137 - more than 15 Qi / km.km \\
\hline 2 & $\begin{array}{l}\text { Erosion (rubbing and } \\
\text { deflection) }\end{array}$ & Degree of soil erosion & $\begin{array}{l}\text { Blurred, strong and middle-throated, strongly- } \\
\text { and medium-deflated }\end{array}$ \\
\hline 3 & Skeletonism & $\begin{array}{l}\text { The content of debris of rocks is } \\
\text { over } 3 \mathrm{~mm}, \%\end{array}$ & $>20 \%$ from both soil ( $30 \mathrm{~m}$ layer of soil) \\
\hline 4 & $\begin{array}{l}\text { Lightweight } \\
\text { granulometric } \\
\text { warehouse }\end{array}$ & $\begin{array}{l}\text { The content of physical clay } \\
\text { (particles with a diameter of less } \\
\text { than } 0.01 \mathrm{~mm} \text { ), } 5\end{array}$ & $\begin{array}{l}\text { a) Polissia zone - up to } 5 \\
\text { b) the forest-steppe zone - up to } 10 \\
\text { c) Steppe zones and southern areas of the Forest- } \\
\text { Steppe (except the Western) - up to } 20\end{array}$ \\
\hline 5 & $\begin{array}{l}\text { Heavy granulometric } \\
\text { composition }\end{array}$ & $\begin{array}{l}\text { The content of physical clay (often } \\
\text { with a diameter less than } 0.01 \mathrm{~mm} \text { ) }\end{array}$ & $\begin{array}{l}\text { a) in the Carpathian region - more than } 50 \text { in the } \\
\text { other regions, in the province } \\
\text { b) in the forest rocks over } 75\end{array}$ \\
\hline 6 & Humus & Humus content, $\%$ by weight of soil & $\begin{array}{l}\text { a) in Polissya - less than } 0.6 \\
\text { b) in the forest-steppe - less than } 1,5 \\
\text { c) in the Steppe - less than } 2.0\end{array}$ \\
\hline 7 & $\begin{array}{l}\begin{array}{l}\text { Reaction of soil } \\
\text { solution }\end{array} \\
\text { s }\end{array}$ & $\mathrm{pH}$ & $\begin{array}{l}\text { In all zones a) to } 4.0 \\
\text { b) more than } 8.0\end{array}$ \\
\hline 8 & $\begin{array}{l}\text { The content of } \\
\text { movable aluminum }\end{array}$ & $\mathrm{mg} / \mathrm{ekv}$ per 100 soil & Over 3.0 \\
\hline 9 & $\begin{array}{l}\text { Content of absorbed } \\
\text { sodium }\end{array}$ & $\%$ of the amount of absorbed bases & $\begin{array}{l}\text { a) for atomorphic soils - more than } 5 \\
\text { b) for semihydromorphic and hydromorphic } \\
\text { soils - more than } 10\end{array}$ \\
\hline 10 & Salinity & $\begin{array}{l}\% \text { of the weight of the soil, in } \\
\text { terms of toxic salts }\end{array}$ & more than 0,4 \\
\hline 11 & Carbonate & $\begin{array}{l}\text { Carbonate content, } \% \text { by weight of } \\
\text { soil }\end{array}$ & $\mathrm{CaCO}$ more than 30 \\
\hline 12 & Physical degradation & Total mass, g/ cu. cm & $\begin{array}{l}\text { over } 1.5 \text { - for loamy and clay soils; more than } \\
1,9 \text { - for sandy soils and sandy soils }\end{array}$ \\
\hline 13 & Chemical pollution & $\begin{array}{ll}\text { Maximum } & \text { Permissible } \\
\text { Concentration (MPC) } & \end{array}$ & Excessive MAC \\
\hline
\end{tabular}

Source: author's development based on [4] 
They include [3]:

- land plotted as a result of earthquakes, landslides, formation of karst, flood, mining;

- medium and strong, alkaline, excessively moist, with high acidity, salinity, contaminated with chemicals, heavy metals and other compounds dangerous to human health;

- low productive land whose soils are characterized by natural low fertility;

- the land of floodplain of small rivers and streams, as well as drainage of flood lands, which are now in unsatisfactory condition and requiring re-naturalization, that is, their return to a state close to the original one.

All these measures contribute to the restoration of biodiversity and the creation of the best conditions for wildlife and fauna. At the same time, the costs of industrial resources and energy are reduced in support of the fertility of these lands, which generally contributes to reducing the man-made load on the ecosystem [5].

Making a decision about the transition to environmentally sound agriculture and the formation of ecologically clean land masses, it is necessary to clearly follow the transition process. Soil condition for organic certification requires careful attention.

The territory undergoing transformation requires the collection of information and the study of the characteristics of the object. This includes: studying geology, geomorphology and relief; climatic conditions; soil conditions; I will become a contamination of natural resources; On the basis of these data, the definition of agro-ecological types of land is made (Figure 1).

For clarity of research work, cartograms are formed: the slopes of the slopes; thermal resources; soil cover; the situation of the degree of pollution of the territory; complex ampeloecological / agroecological cartograms.

The implementation of ecologically safe use of land requires the creation of a comprehensive map of the suitability of areas for cultivating crops, which depicts the quality characteristics of the territory in accordance with agroecological requirements of agricultural crops, the main directions of the use of nature and their respective functional areas in the planning area, including boundaries, land area, and also, the degree of suitability of these or other cultures. The data is shown on such maps, will serve to deepen the national, regional and local distribution of agricultural specialization, provide the territorial and agroecological characteristics of the land masses, geographic location of land of different agroecological significance.

On the basis of which one can calculate the economic efficiency of concentrating the production of the bulk of the necessary agricultural products and obtain the characteristics of natural resource potential, the objectives of nature conservation and the real use of the territory, as well as recommendations for environmentally appropriate nature management.

Eco-bonite analysis of the object will be required to identify the most suitable sites for the transition to ecologically clean land massifs, as well as territories requiring a complex of reproductive measures.

For easy land management and project design, land masses requiring the same intensity of use, agrotechnics and suitable for cultivation of certain types of crops need to be consolidated. Consolidation is an association of land in agro-landscape zones, homogeneous in terms of genetic, hydrological, geomorphological features, and microclimatic conditions that form an agro-landscaped array.

Within the allocated areas it is necessary to organize a group of agro-landscape arrays in shape, steepness and length of slopes and other indicators. For each group to define adaptive crop rotation, which is adapted to the data of soil and ecological conditions.

The objects of transformation to ecologically clean land masses require the implementation of measures for anti-erosion of the territory (creation of forest belts, road networks, earthworks, watercourses, formation of protective coastal protective bands), as well as intra-territorial organization of the territory, the definition of working and technological areas within the fields. 


\section{ORDER OF THE ECONOMIC AGROECOLOGICAL SITUATION OF THE TERRITORY}

The choice of the land mass for transformation into ecologically clean

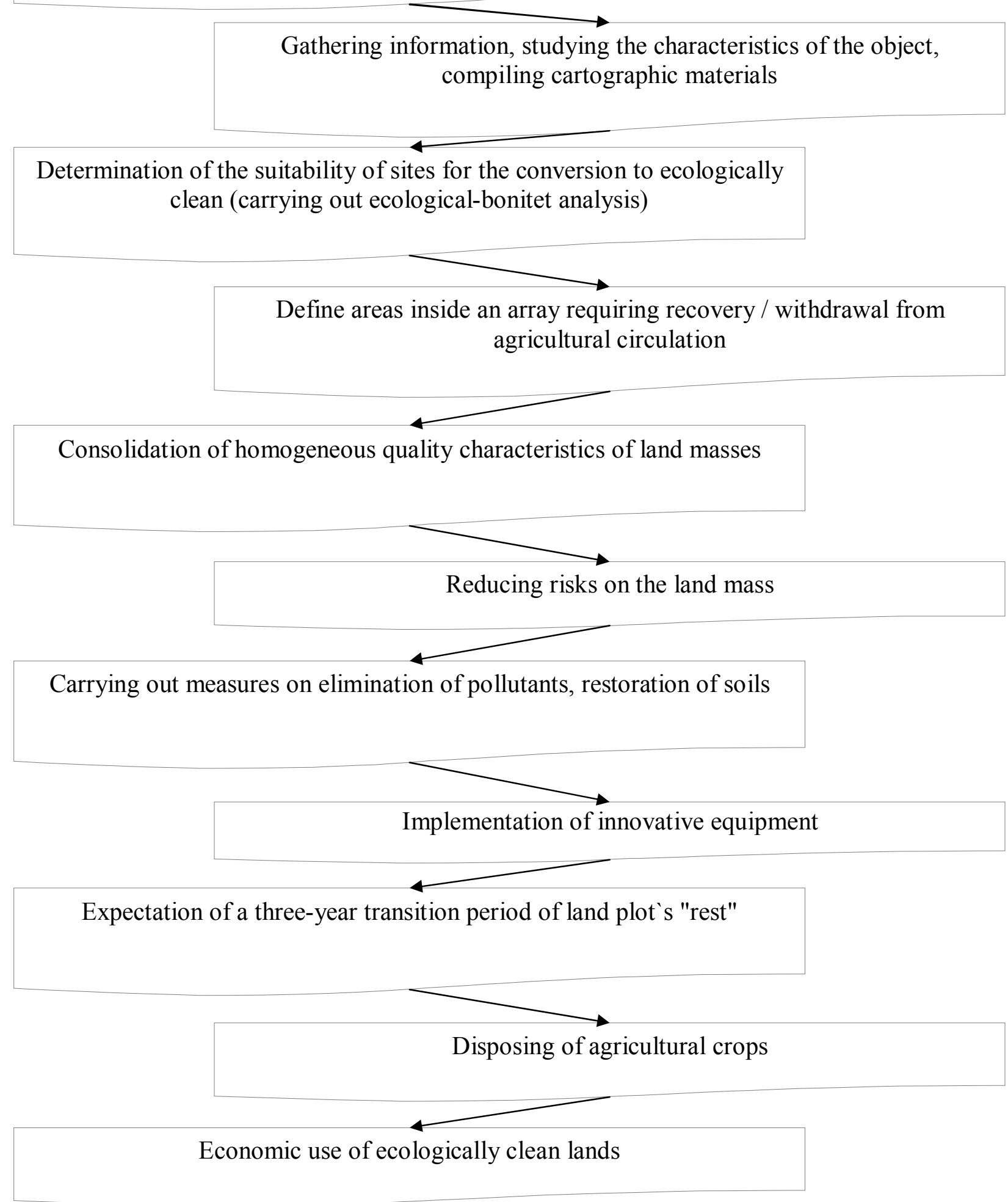

Fig.1. Stages of the economic agroecological organization of the territory Source: author's development 
Fields are designed with the following conditions: ensuring the uniformity of the field on the suitability of soils for the cultivation of individual crops; provision of agricultural uniformity. As a result of different variants, preference is given to agroecological characteristics, since the non-conformity of the agrobiological requirements of some crops to the soil cover is more weighty than other negative factors that reduce yields.

To preserve the reproducible natural state of the land mass, a system of environmental and soil protection measures is being developed that ensure the ecological balance of the environment and the ecological safety of agricultural production (Figure 2).
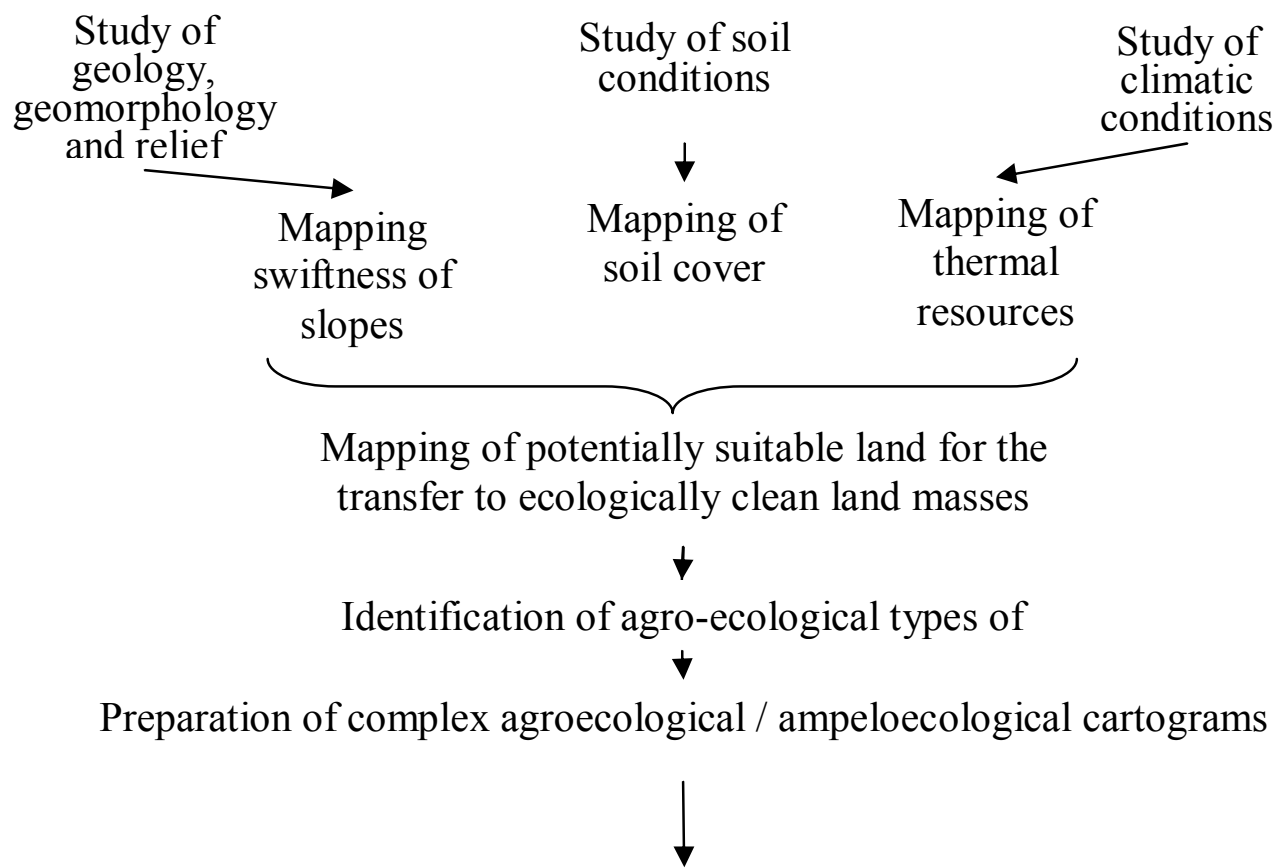

Adoption of design

decisions

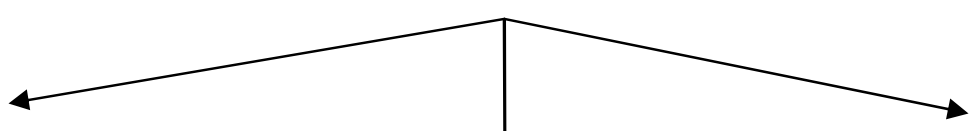

Rationalization of the ratio and balance of the main element and production conditions

Organizationally production

Resettlement

Placement of industries of production and economic centers
Formation of organizational and territorial conditions Application of innovative technolooies

Scientific organization of labor

Management of agricultural production

Creation of a system of land-

valuation norms

Planning

Management

Taxation

Fig.2. Agroecological organization of the territory of economic entities

Source: author's development 
The system of transition to environmentally safe production with the creation of ecologically clean land masses for each form of ownership of the enterprise is conducted in a similar way (Figure 3 ).

The only thing that distinguishes the creation of lands with special characteristics is the type of development of the land mass: onetime and step-by-step.
The one-time transition causes the choice of land masses of the reference quality. In the opinion of the author, the use of this type of land is best suited for state-owned enterprises that can provide leadership, use and protection of resources from a single center.

High quality of land masses will allow to concentrate financial resources in the budget and use them for solving problems in nature management.

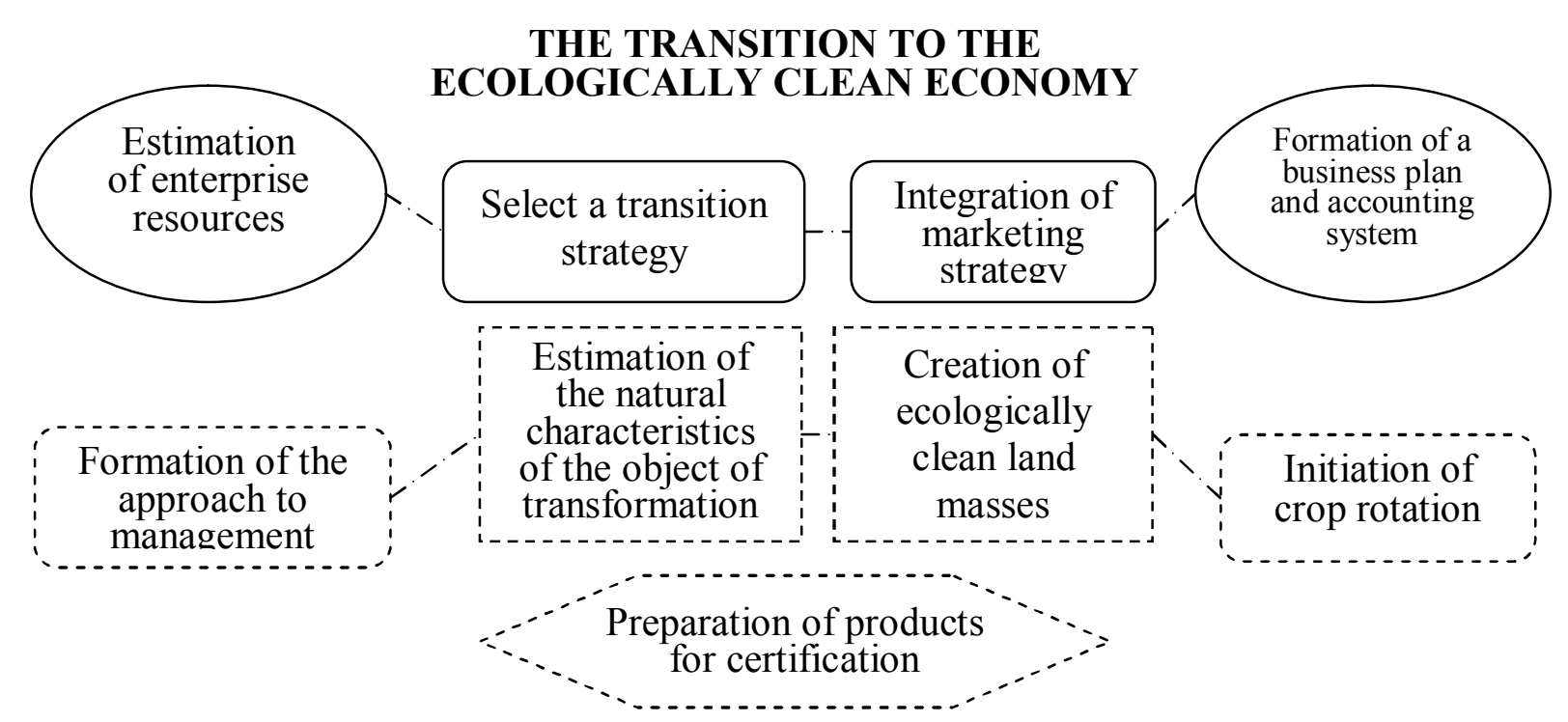

Fig.3. Block figure of the planning of transition to ecologically clean agricultural land Source: author's development

The gradual development of land of lower quality, which includes a number of reproductive measures, is better suited for private-ownership enterprises. In this case, part of the income from the use of this land resource is assigned to the private owner, the other part is sent in the form of payments on the basis of environmental rent for the land (tax). The owner of the natural resource will be interested in improving the quality of his land, as the rent, remains with the owner with the opportunity to direct it for rational use, protection and reproduction of the land mass with further increase in its quality and selling price [7] (Figure 4).

Complex problems that an enterprise of any ownership type may encounter when switching to environmentally sound farming can look like: risk management; planning of crop rotation; yield planning; pest and insect fighting; disease control of plants; elimination of pollutants (for a private enterprise); introduction of innovative equipment; quality management of products; search for product buyers; search markets for product sales.

The agroecological organization of the territory includes a system of levers of state management of rational ecologically safe use of agricultural land.

Ukrainian enterprises focusing on the formation of ecologically clean land masses and the maintenance of environmentally sound agriculture require state support, along with a reduction of a fixed land tax, the introduction of a simplified tax system and the replacement of the payment of income tax to raise wages for farm workers, in order to increase the employment of the population and work quality. 


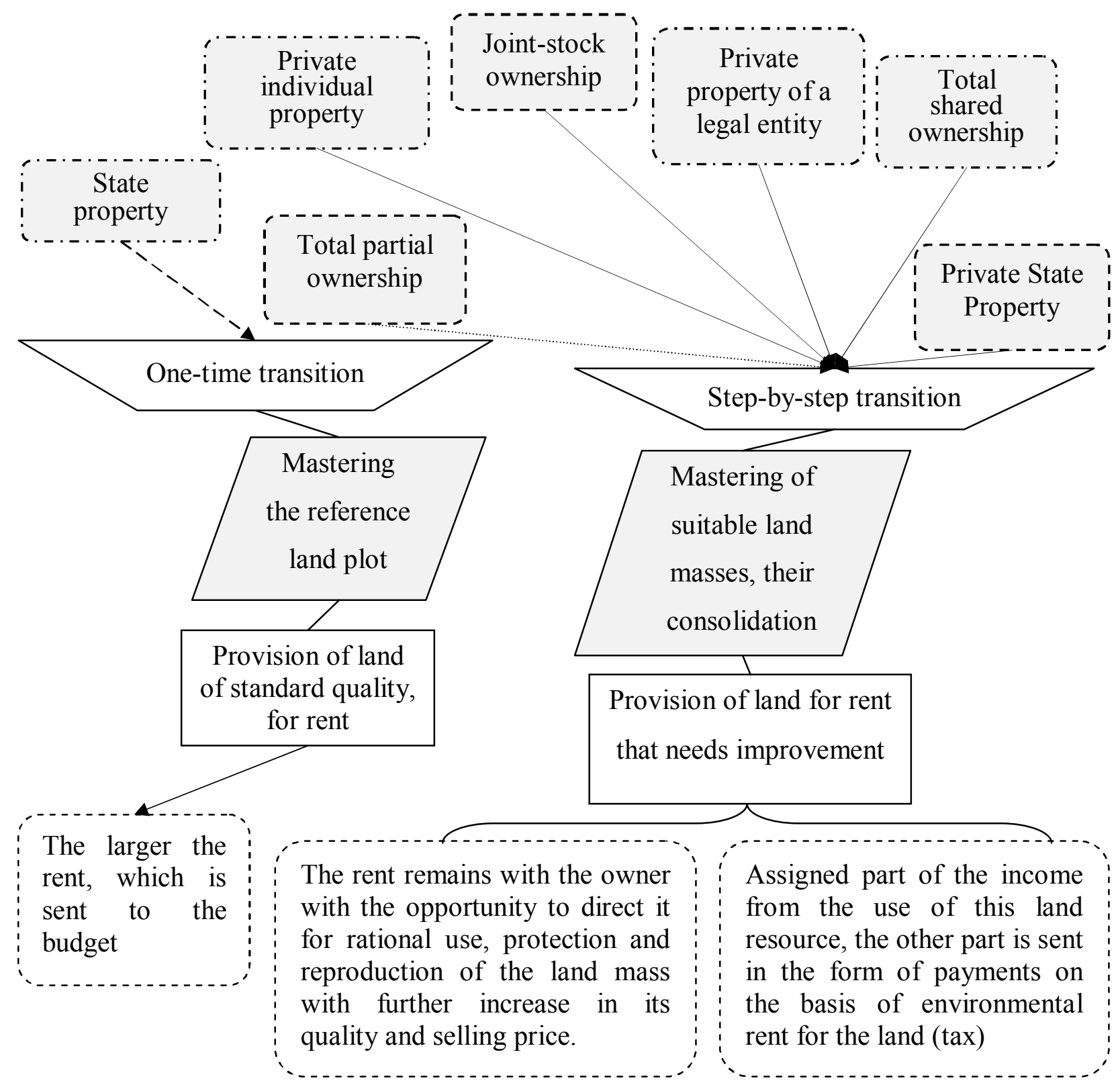

Fig.4. Scheme of implementation of ecologically clean land mass in circulation of various organizational forms of agricultural enterprises

Source: author's development based on [7], [8]

In many countries of the world, the legislation provides for the payment of subsidies to farmers who supply the final product to the market. In Ukraine, still certified organic farms do not receive any subsidies from the state, therefore the price for the final organic product remains slightly higher than the conventional analogue [9].

A mandatory measure for the further development of the organic sector and ecologically safe agricultural production in general is the creation of a mechanism for motivating the formation of ecologically clean land masses and the production of ecologically clean products by agrarian enterprises, which will take into account the world tendencies of development of this sphere of management. 


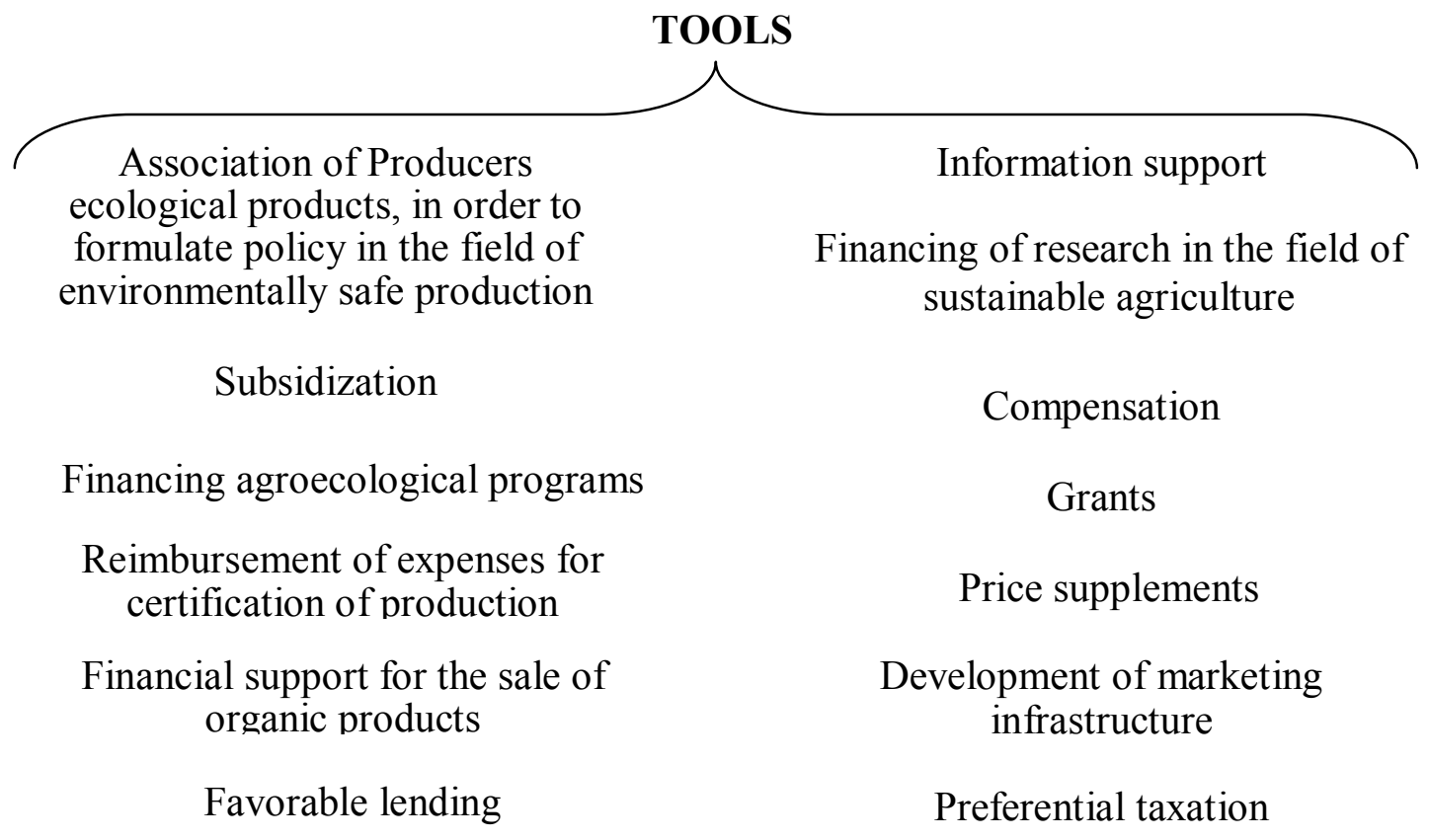

Fig.5. Tools for motivating agricultural enterprises to create ecologically clean land massifs Source: author's development based on [10, p. 195-201]

Conclusions and further research. Environmental management requires a clear change in the farming system. Restoring and improving the natural condition of the agrolandscape, in order to synthesize the most ecologically clean land massifs for the restoration of bioproductivity of the land, the creation of ecologically pure land masses serves to create humus formation.

However, the transformation of land masses in an ecologically clean way requires a 2-3-year transitional period.

The study of territories to translate them into ecologically safe requires a detailed collection and study of information on the characteristics of the objects. On the basis of collected and analyzed data, arrays may be subject to evaluation and differentiation by the nature of development for use by enterprises of various forms of ownership, with the aim of further improving the quality and their implementation.

As a result of a rather complicated procedure for the transfer to ecologically clean land masses, there is a pressing need to develop a system of measures to adapt agricultural production by individual enterprises to the features of the new natural environment and to provide state support in the form of subsidies, compensations, price supplements and other subsidies, infrastructure, information and legal instruments of motivation. 


\section{REFERENCES}

1. Dobriak, D.S., Kanash, O.P., Babmindra, D.I., \& Rozumnyi, I.A. (2009) Classification of agricultural land as a scientific precondition of ecologically safe use. Kyiv: Urozhai, 464 [in Ukrainian].

2. Antipov, A.N., \& Semenov, YU.M. (2006) Ecologically orientated planirovanie land use in Prikailie. Irkutsk. 5, 23 [in Russian].

3. The Land Code of Ukraine: Law on 25.10.2001 No. 2768-III (2002). News of the Verkhovna Rada of Ukraine, 3,27 [in Ukrainian].

4. Sokhnich, A.Ya., \& Kolodiy, P.P. (2005) State control over the use and protection of land: teaching. Manual. Lviv, Ukrainian Technology Technology Foundation, 81, 140. [in Ukrainian].

5. Bondar, O.I., Timchenko, O.I., \& Tararico O.G. (2006). Anthropogenic factors of the environment and their influence on biota and human health: a textbook. Interest, 288 [in Ukrainian].

6. Organic Products Regulations (2009). Minister of Justice at the following address. Retrived from: http://laws-lois.justice.gc.ca.

7. Martiienko, A.I. (2011). The theoretical basis of property relations on natural resources. Odesa: Instytut problem rynku ta ekonomiko-ekolohichnykh doslidzhen NAN Ukrainy [in Ukrainian]

8. Kupiniets, L.Ye., (2010). Ecologization of the food complex: theory, methodology, mechanisms. Odesa: Izd-vo IPREEI NAN Ukrainy, 720 [in Russian].

9. Krynytska, O.O. (2015). Institutional support for the development of land relations of Ukraine. Candidate's thesis. Odesa, [in Ukrainian].

10. Oliinyk, O.R. (2014). International experience of stimulating the development of organic production and its use in domestic practice. Innovative economy, 195-201 [in Ukrainian].

11. Kupiniets, L.Ye., \& Tiutiunnyk, H.O. (2017). The quality of soils in the system of agricultural economic management. Economic innovation, 63, 116-125 [in Ukrainian].

\section{ЛІТЕРАТУРА}

1. Класифікація сільськогосподарських земель як наукова передумова їх екологобезпечного використання. Київ: Урожай, 2009. С. 4-91.

2. Антипов А.Н. Экологически ориентированное планирование землепользования в Прибайкалье. Институт географии им. В.Б. Сочавы. Иркутск, 2006. С. 5.

3. Земельний кодекс України: Закон від 25.10.2001 № 2768-III / Відомості Верховної Ради України від 25.01.2002. 2002 р. № 3. Стаття 27.

4. Сохнич А.Я. Державний контроль за використанням і охороною земель : навч. Посібник. Львів, НВФ «Українські технології», 2005. С. 81.

5. Бондар O.I., Тимченко O.I., Тараріко О.Г. Антропогенні чинники довкілля та їх вплив на біоту і здоров'я людини: підручник Київ: Інтерес, 2006. 288 с.

6. Organic Products Regulations (2009). Minister of Justice at the following address. URL: http://laws-lois.justice.gc.ca

7. Мартієнко А.I. Теоретичні основи розвитку відносин власності на природні ресурси. Одеса: Інститут проблем ринку та економіко-екологічних досліджень НАН України, 2011. C. $336-350$

8. Купинец Л.Е. Экологизация продовольственного комплекса: теория, методология, механизмы. Одесса: Изд-во ИПРЭЭИ НАН Украины, 2010.С.720.

9. Криницька О.О. Інституційне забезпечення розбудови земельних відносин України [Текст] : дис. ... кандидата екон. наук : спец. 08.00.03 / О.О. Криницька ; НАН України, Ін-т проблем ринку та економіко-екологічних досліджень. Одеса, 2015. 224 с.

10. Олійник О.Р. Міжнародний досвід стимулювання розвитку органічного виробництва та його використання у вітчизняній практиці. Інноваційна економіка. 2014. №4(53). С. 195-201

11. Тютюнник Г.О. Якість грунтів в системі забезпечення агрогосподарського природокористування. Економічні інновації. 2017. № 63. С. 116-125. 